\title{
Hypoglycemic Effect of Kyllinga triceps in STZ Induced Diabetic Rats
} Lal VK ${ }^{1}$, Gupta PP ${ }^{2}$ and Pandey Awanish ${ }^{3 *}$

${ }^{1}$ Department of Pharmacy, SITM, Barabanki, UP, India

${ }^{2}$ B.R.D.Medical College, Gorakhpur, UP, India

${ }^{3}$ Research Scholar, UTU, Dehradun, Uttarkhand, India

\begin{abstract}
Kyllinga triceps is an Indian medicinal plant demonstrated to exert multiple pharmacological effects. In light of traditional claim of the plant in treatment of diabetes, the present study was carried out to evaluate the hypoglycemic activity of the plant in Streptozotocin (STZ) induced diabetic rats. The diabetic rats were given Kyllinga triceps extract $(\mathrm{KTE}, 100 \mathrm{mg} / \mathrm{kg} \& 200 \mathrm{mg} / \mathrm{kg}$ ) and Glibenclamide $(0.5 \mathrm{mg} / \mathrm{kg})$ for 28 days. The effects of both treatments on body weight and blood glucose were assessed. Both doses of extract and Glibenclamide showed significant hypoglycemic activity in acute and sub acute study. Body weight of extract and glibenclamide treated rats were maintained during the study period Where as body weight of untreated rats had gone down. The result obtained from the study scientifically proved the folkloric use of Kyllinga triceps as hypoglycemic agent. Thus the plant can be key contributor in treatment of Diabetes.
\end{abstract}

Keywords: Diabetes; Glibenclamide; Hypoglycemic; Kyllinga triceps

\section{Introduction}

Type 2 diabetes mellitus, also known as noninsulin dependent diabetes mellitus, develops in middle or later life and affects $2-6 \%$ of adults in most Western societies [1]. Diabetes mellitus has been recognized as a growing world-wide epidemic by many health's advocacy groups including the World Health Organization (WHO) [2]. The WHO has estimated that diabetes will be one of the worlds leading causes of death and disability within the next quarter century. The statistics are alarming; 30 million people were diagnosed with diabetes world-wide in 1985, by 1995 the number had risen to 135 million, and at the current rate there will be 300 million by the year 2025 as predicted by the WHO [3].

The limitations of currently-available oral antidiabetic agents either in terms of efficacy/safety coupled with the emergence of the disease into a global epidemic have encouraged a concerted effort to discover drugs that can manage type 2 diabetes more efficiently [4]. Also, with increasing incidence of diabetes mellitus in rural population throughout the world and due to adverse effects of synthetic medicine, there is a clear need for development of indigenous, inexpensive botanical sources for anti-diabetic crude or purified drugs [5].

Medicinal plants use has turned out to be an alternative method for treatment of disease such as diabetes mellitus. Literature reports more than 800 plants have been utilized as empirical treatment for diabetes. One tenth of them have been characterized as hypoglycemic plants with active compounds such as mucilage gum, glycans, flavonoids, triterpenes and alkaloids [6].

Research conducted in last few decades on plants mentioned in ancient literature or used traditionally for diabetes has shown antidiabetic property.

The recommendation of the WHO committee on diabetes encouraging research on hypoglycemic agents of plant origin used in traditional medicine has greatly motivated research in this area [7]. Currently several hundred plants have been reported to have beneficial effect in treatment of diabetes [8-10].

Kyllinga triceps (Family: Cyperaceae) is common throughout India found specially in Northwestern India, Gujarat, Rajasthan and South
India. It is also known as Nirvishaa, Nirbishi and Mustaa. Its root is used as diuretic (in polyuria), demulcent, antidermatosis and antidiabetic [11]. Decoction of the plant Kyllinga triceps showed antipyretic activity [12].

Different ethnic communities of Thoubal district of Manipur used to treat diabetes by 54 plant species. Boiled plant extract is used to treat diabetes by village priests cum doctors (Locally called Maida or Maidi) [13]. Jain et al reported that Kyllinga triceps is used to treat diabetes by local folklore and tribals of different districts of Madhya Pradesh and Chattisgarh [14].

In the present study we have selected Kyllinga triceps to examine its hypoglycemic activity because traditional documents claimed that to be an antidiabetic and used as folkloric medicine in different region of India.

\section{Methodology}

\section{Collection of plants}

The plant was collected and authenticated by the comparison with the herbarium and voucher specimen (Voucher specimen No. 97767) was lodged in the department herbarium of National Botanical Research Institute, Lucknow.

\section{Preparation of plant extract}

Plants were shade dried, milled, and ground into coarse powder with the help of a mixer. The powdered material was subjected to cold maceration using sufficient quantity of ethanol and distilled water (1: 1) for 10 days with intermittent shaking in a round bottom flask. On $10^{\text {th }}$ day, it was strained and marcs were pressed. The pressed liquid was

*Corresponding author: Awanish Kumar Pandey, Research Scholar, UTU, Dehradun, Uttarkhand, India, E-mail: awanishpandey@rediffmail.com

Received March 05, 2012; Accepted July 06, 2012; Published July 10, 2012

Citation: Lal VK, Gupta PP, Awanish P (2012) Hypoglycemic Effect of Kyllinga Triceps in STZ Induced Diabetic Rats. J Diabetes Metab 3: 204. doi:10.4172/21556156.1000204

Copyright: (c) 2012 Lal VK, et al. This is an open-access article distributed under the terms of the Creative Commons Attribution License, which permits unrestricted use, distribution, and reproduction in any medium, provided the original author and source are credited. 
added to the strained liquid and the combined liquid was clarified by filtration and the filtrate was subjected to distillation at temperature $60^{\circ} \mathrm{C}$ for removing ethanol and water. After distillation, the semi solid obtained was kept for experiment.

\section{Experimental animals}

Healthy wistar albino rats were used for the study. They were maintained at standard laboratory condition and fed with commercial pellet diet and water ad libitum. The animals were acclimatized to laboratory condition for one week before commencement of experiment.

\section{Acute oral toxicity study}

In present study observation of acute toxicity study carried according to OECD guideline 423, none of the rats showed observable signs of toxicity upon single administration of kyllinga extract ( $2 \mathrm{~g} /$ $\mathrm{kg}$, p.o.) on day one. Observations twice daily for 14 days also did not reveal any drug related observable changes. The study was repeated with another set of animals for 14 days and no signs of toxicity were observed.

\section{Induction of diabetes}

Rats were fasted overnight before inducing diabetes with streptozotocin. The rats were given an intraperitoneal injection of streptozotocin $(50 \mathrm{mg} / \mathrm{kg}$ ) freshly prepared in $0.1 \mathrm{M}$ sodium citrate buffer. The diabetic state was confirmed $48 \mathrm{~h}$ after streptozotocin injection. Threshold value of fasting blood glucose was taken as $>200$ mgldl.

Control and diabetic rats were weighed matched for body weight and divided into following group consisting five animals each.

Group I - Non diabetic control

Group II - Diabetic Control

Group III -Diabetic rats administered with Glibenclamide at dose of $(0.5 \mathrm{mg} / \mathrm{kg})$

Group IV -Diabetic rats administered with Kyllinga triceps extract (KTE) in dose of $100 \mathrm{mg} / \mathrm{kg}$

Group V - Diabetic rats administered with Kyllinga triceps extract (KTE) in dose of $200 \mathrm{mg} / \mathrm{kg}$

The acute study involved estimation of blood glucose levels at 0,2 , 4, 6 and 24 hrs after administration of Glibenclamide and KTE.

The sub acute study involved daily administration of Glibenclamide and KTE for 28 days and blood glucose levels were estimated on 0 , $7,14,21$ and 28 days.

\section{Blood glucose estimation}

Blood samples were obtained through puncture tail vein and collected blood samples were analyzed by Accu-Check Glucometer. Blood glucose levels were expressed in terms of mg\dl.

\section{Body weight determination}

Weight of rats was recorded during the study period of 28 days. Percentage (\%) change in body weight was calculated and tabulated.

\section{Results}

In acute toxicity studies of Kyllinga extract given by oral route did not show any mortality and toxic effects up to the dose of 2000 mg $\backslash \mathrm{kg}$ body weight. So $1 \backslash 20^{\text {th }}$ and $1 \backslash 10^{\text {th }}$ of safe dose is used for the experiments.

STZ- induced diabetic rats exhibiting persistent hyperglycemia (Blood Glucose $>200 \mathrm{mg} \backslash \mathrm{dl}$ ) were selected for assessing the effect of KTE. Table 1 shows the blood glucose level at various time intervals to observe acute effect of two different doses of KTE and Glibenclamide. Data showed significant $(\mathrm{p}<0.05)$ difference in blood glucose of all the treatments compared to diabetic control. Glibenclamide showed highest \% decrease (45.7\%) followed by KTE (200 mg/kg) $(40.0 \%)$. KTE $(100 \mathrm{mg} / \mathrm{kg})$ showed lowest \% decrease $(36.4 \%)$ in blood glucose level. It is clear from the data that KTE $(200 \mathrm{mg} / \mathrm{kg})$ showed more hypoglycemic activity than KTE $(100 \mathrm{mg} / \mathrm{kg})$ in acute study.

To observe long term effect, sub acute study of 28 days was done. Table 2 shows the results of this study. Glibenclamide and KTE (200 mg/ $\mathrm{kg}$ ) showed highly significant $(\mathrm{p}<0.01)$ hypoglycemic effect compared to diabetic control while KTE $(100 \mathrm{mg} / \mathrm{kg})$ also showed significant $(\mathrm{P}<$ $0.05)$ hypoglycemic activity. KTE $(200 \mathrm{mg} / \mathrm{kg})$ showed less \% reduction (47.2\%) than Glibenclamide (55.4\%). In sub acute study also KTE $(200 \mathrm{mg} / \mathrm{kg})$ is more effective than KTE $(100 \mathrm{mg} / \mathrm{kg})$.

\begin{tabular}{|l|l|l|l|l|l|}
\hline \multirow{2}{*}{ GROUPS } & \multicolumn{5}{|c|}{ BLOOD GLUCOSE (mgldl) } \\
\cline { 2 - 6 } & $0 \mathrm{hr}$ & $2 \mathrm{hr}$ & $4 \mathrm{hr}$ & $6 \mathrm{hr}$ & $24 \mathrm{hr}$ \\
\hline Normal Control & $93 \pm 1.9$ & $93 \pm 2.7$ & $95 \pm 1.2$ & $94 \pm 3.1$ & $91 \pm 1.4$ \\
\hline Diabetic Control & $230 \pm 2.4$ & $237 \pm 1.6$ & $239 \pm 3.2$ & $244 \pm 2.1$ & $254 \pm 4.1$ \\
\hline Diabetic+ Glibenclamide & $247 \pm 2.3$ & $194 \pm 2.7^{*}$ & $158 \pm 1.8^{*}$ & $134 \pm 1.1^{*}$ & $197 \pm 3.6$ \\
\hline $\begin{array}{l}\text { Diabetic+ KTE } \\
\text { (100 mglkg) }\end{array}$ & $222 \pm 3.7$ & $193 \pm 2.4^{*}$ & $164 \pm 2.3^{*}$ & $141 \pm 1.9^{*}$ & $202 \pm 2.8$ \\
\hline $\begin{array}{l}\text { Diabetic+ KTE } \\
\text { (200 mglkg) }\end{array}$ & $220 \pm 2.4$ & $185 \pm 4.3^{*}$ & $152 \pm 3.1^{*}$ & $131 \pm 2.7^{*}$ & $190 \pm 3.8$ \\
\hline
\end{tabular}

All values are expressed as mean \pm S.E.M $(n=5)$. ${ }^{*} P<0.05$ as compared to diabetic control. One-way ANOVA followed by Dunnet multiple comparison test

Table 1: Acute effect of KTE on blood glucose level in STZ induced diabetic rats.

\begin{tabular}{|l|l|l|l|l|l|}
\hline \multirow{2}{*}{ GROUPS } & \multicolumn{5}{|c|}{ BLOOD GLUCOSE (mgldl) } \\
\cline { 2 - 6 } & 0 DAY & 7 DAY & 14 DAY & 21 DAY & 28 DAY \\
\hline Normal Control & $93 \pm 2.7$ & $101 \pm 2.2$ & $100 \pm 2.6$ & $98 \pm 1.8$ & $102 \pm 3.1$ \\
\hline Diabetic Control & $230 \pm 3.8$ & $242 \pm 2.4$ & $258 \pm 1.9$ & $276 \pm 3.8$ & $298 \pm 2.1$ \\
\hline $\begin{array}{l}\text { Diabetic+ Gliben- } \\
\text { clamide }\end{array}$ & $247 \pm 1.9$ & $210 \pm 2.9^{* *}$ & $180 \pm 1.2^{* *}$ & $151 \pm 4.3^{* *}$ & $110 \pm 3.7^{* *}$ \\
\hline $\begin{array}{l}\text { Diabetic+ KTE } \\
\text { (100 mglkg) }\end{array}$ & $222 \pm 2.2$ & $206 \pm 3.1^{*}$ & $190 \pm 3.6^{*}$ & $174 \pm 1.1^{*}$ & $137 \pm 3.9^{*}$ \\
\hline $\begin{array}{l}\text { Diabetic+ KTE } \\
\text { (200 mglkg) }\end{array}$ & $220 \pm 3.1$ & $191 \pm 2.9^{* *}$ & $164 \pm 2.7^{* *}$ & $141 \pm 4.2^{* *}$ & $116 \pm 1.9^{* *}$ \\
\hline
\end{tabular}

All values are expressed as mean \pm S.E.M $(n=5)$. ${ }^{*} P<0.05,{ }^{* *} P<0.01$ as compared to diabetic control. One-way ANOVA followed by Dunnet multiple comparison test

Table 2: Sub acute effect of KTE on blood glucose level in STZ induced diabetic rats.

\begin{tabular}{|l|l|l|l|l|l|}
\hline \multirow{2}{*}{ GROUPS } & \multicolumn{5}{|c|}{ BODY WEIGHT (gm) } \\
\cline { 2 - 6 } & 0 DAY & 7 DAY & 14 DAY & 21 DAY & 28 DAY \\
\hline Normal Control & $140 \pm 3.9$ & $142 \pm 4.2$ & $144 \pm 1.9$ & $145 \pm 3.9$ & $145 \pm 3.2$ \\
\hline Diabetic Control & $158 \pm 4.7$ & $154 \pm 4$ & $150 \pm 3.7$ & $148 \pm 2.9$ & $142 \pm 1.7$ \\
\hline $\begin{array}{l}\text { Diabetic+ Gliben- } \\
\text { clamide }\end{array}$ & $139 \pm 1.8$ & $139 \pm 2.3^{* *}$ & $140 \pm 3.5^{* *}$ & $144 \pm 1.6^{* *}$ & $148 \pm 4.1^{* *}$ \\
\hline $\begin{array}{l}\text { Diabetic+ KTE } \\
\text { (100 mglkg) }\end{array}$ & $139 \pm 1.9$ & $139 \pm 2.8^{*}$ & $143 \pm 2.4^{*}$ & $144 \pm 3.4^{*}$ & $146 \pm 2.9^{*}$ \\
\hline $\begin{array}{l}\text { Diabetic+ KTE } \\
\text { (200 mglkg) }\end{array}$ & $162 \pm 2.3$ & $164 \pm 2.6^{* *}$ & $164 \pm 3.6^{* *}$ & $167 \pm 4.5^{* *}$ & $171 \pm 4.1^{* *}$ \\
\hline
\end{tabular}

All values are expressed as mean \pm S.E.M $(n=5)$. ${ }^{*} P<0.05$, ${ }^{* *} P<0.01$ as compared to diabetic control. One-way ANOVA followed by Dunnet multiple comparison test

Table 3: Effect of KTE on body weight in STZ induced diabetic rats. 
Citation: Lal VK, Gupta PP, Awanish P (2012) Hypoglycemic Effect of Kyllinga Triceps in STZ Induced Diabetic Rats. J Diabetes Metab 3: 204. doi:10.4172/2155-6156.1000204

Page 3 of 3

Table 3 shows the body weight of rats at different time intervals during the study. The $\%$ change in body weight of all the treatments was calculated. Non diabetic control showed 3.4\% increase in body weight while diabetic control showed $10.1 \%$ weight decrease .Glibenclamide, $\mathrm{KTE}(200 \mathrm{mg} / \mathrm{kg})$ and $\mathrm{KTE}(100 \mathrm{mg} / \mathrm{kg})$ showed $6.4,5.0$ and $5.5 \%$ increase in body weight respectively. All the treatments showed more $\%$ increase in body weight than non diabetic control. KTE $(200 \mathrm{mg} /$ $\mathrm{kg})$ and KTE $(100 \mathrm{mg} / \mathrm{kg})$ showed nearly similar effect on body weight. So KTE not only showed significant hypoglycemic activity but also effective in preventing the weight loss due to diabetes.

\section{Discussion}

Streptozotocin is well known for its selective pancreatic islets $\beta$ cell cytotoxicity and has extensively used to induce diabetes in experimental rat model. It interferes with cellular metabolic oxidative mechanism. Glibenclamide is often used as a standard antidiabetic drug in STZ induced moderate diabetes to compare the efficacy of variety of hypoglycemic compounds or plant extracts. The present study was conducted to assess the hypoglycemic activity of Kyllinga extract in STZ induced diabetic rats. Results shows both the doses of Kyllinga extract significantly improving the body weight and controlling the blood glucose level in diabetic rats. $200 \mathrm{mg} \backslash \mathrm{kg}$ dose is more effective than $100 \mathrm{mg} \backslash \mathrm{kg}$ and comparable to Glibenclamide. Result of the study scientifically validates the folkloric use of Kyllinga triceps in different ethnic communities of Manipur, Madhya Pradesh and Chhattisgarh.

It may be concluded that Kyllinga extract possess hypoglycemic activities and the plant extract may be used as hypoglycemic agent. The plants should be considered as an excellent candidature for further studies on diabetes mellitus.

\section{References}

1. Bailey CJ (2000) Potential new treatments for type 2 diabetes. Trends Pharmacol Sci 21: 259-265.

2. Prevention of diabetes mellitus. Report of a WHO Study Group. (1994) World Health Organ Tech Rep Ser 844: 1-100.

3. Diabetes Mellitus (1999) World Health Organization Fact Sheet 138.

4. Ranjan C, Ramanujam R (2002) Diabetes and insulin resistance associated disorders: Disease and the therapy. Curr Sci 83: 1533-1538.

5. Alam K, Mahpara S (2003) Role of diet, nutrients, spices and natural products in diabetes mellitus. Pak J Nutr 2: 1-12

6. Acosta-Patino JL, Jimenez-Balderas E, Juarez-Oropeza MA, Diaz-Zagoya JC (2001) Hypoglycemic action of Cucurbita ficifolia on type 2 diabetic patients with moderately high blood glucose levels. J Ethanopharmacol 77: 99-101.

7. World Health Organization (1980) The WHO Experts Committee on Diabetes Mellitus. Technical Report Series, World Health Organization, Geneva.

8. Hill JO, Peters JC (2002) Biomarkers and functional foods for obesity and diabetes. Br J Nutr 88: S213-S218.

9. Kar A, Choudhary BK, Bandopadhyay NG (2003) Comparative evaluation of hypoglycemic activity of some Indian medicinal plants in alloxan diabetic rats. J Ethnopharmacol 84: 105-108.

10. Srinivasan K (2005) Plant foods in the management of diabetes mellitus. Spices as beneficial antidiabetic food adjuncts. Int J Food Sci Nutr 56: 399-414.

11. Khare CP. Indian medicinal plants. Springer 356

12. Choudhary MD, Bawari M, Singha SL (2010) Some Antipyretic Ethno-medicinal Plants of Manipuri Community of Barak Valley, Assam, India. Ethnobotanical leaflets 14: 21-28.

13. Habibullah KM, Yadava PS (2010) Antidiabetic plants used in Thoubal district of Manipur, Northeast India. Indian journal of Traditional Knowledge 9: 510-514.

14. Jitendra JB, Sheetal CK, Bhattacharya S (2006) Medicinal flora of Madhya Pradesh and Chattisgarh- A Review. Indian journal of Traditional Knowledge 5: 237-242. 